This is a self-archived version of an original article. This version may differ from the original in pagination and typographic details.

Author(s): Lohtaja, Aleksi

Title: Architectural Utopias as Methods for Experimenting with the (Im)Possible

Year: 2020

Version: Accepted version (Final draft)

Copyright: (c) Author \& Zed Books, 2020

Rights: In Copyright

Rights url: http://rightsstatements.org/page/lnC/1.0/?language=en

Please cite the original version:

Lohtaja, A. (2020). Architectural Utopias as Methods for Experimenting with the (Im)Possible. In T. Eskelinen (Ed.), The Revival of Political Imagination : Utopia as Methodology (pp. 133-150).

Zed Books. https://doi.org/10.5040/9781350225633.ch.008 


\title{
8 Architectural Utopias as Methods for Experimenting with the (Im)Possible
}

\author{
Aleksi Lohtaja \\ Architecture is often considered to be a form of art, in which ideological and utopian \\ dimensions are intertwined. Compared to other forms of art, such as poetry, literature, music, \\ or painting with a utopian function to envision imaginary worlds which critically counter the \\ present, architecture never entirely flees from current society and its material basis. Instead, its \\ utopian aspirations are always materialized through a social and political framework and its \\ restrictions. In this sense, architectural utopianism seems to manifest Karl Mannheim's (1936) \\ seminal argument regarding the coexistence of utopias and ideologies: political ideologies are \\ 'realised' versions of utopian aspirations. However, the extent to which this defines the \\ emancipatory potential of architecture (or utopias in general), is debatable.
}

The relationship between utopia, architecture and ideology is central to cultural theorist Fredric Jameson in his essay 'Architecture and the Critique of Ideology' (Jameson 2000; for a broader contextualization of this text, see Lahiji 2012). In the essay Jameson distinguishes (1) a very critical reading on the relationship between architecture and ideology in the works of Italian architectural theorist Manfredo Tafuri (1935-1994) and (2) more affirmative yet also critical approach to the same matter in the work of French philosopher Henri Lefebvre (1901-1991). For both Lefebvre and Tafuri, it is precisely the close connection between utopianism and ideologies that encloses architecture's role in society. However, even though these two disciplinary approaches to architecture share the idea that architecture reflects the broader conditions and ideologies of society, their conceptualizations of political uses and potentialities for utopias differ fundamentally.

Can these different positions be taken to clarify the contemporary use of the concept of utopia in political and social theory? This article attempts to understand, in which way architectural utopias can be taken as methods for socio-political change (as discussed in the Introduction, see also Levitas 2013; Moylan \& Baccolini 2007). I propose that (architectural) utopias are not inherently political in an emancipatory sense, nor do they however function only as plain 
ideologies subordinated to reinforced political goals. Instead, I consider utopias as a way to mediate politics and configure another pathway for the future, which implies always a utopian horizon. Rather than thinking this in an ahistorical manner covering architectural utopias in general, my special focus is a critical reading towards modernist architectural utopianism offered by Tafuri and Lefebvre. Utopian thought has of course always implied certain architecture aspects, but the modification of space as an inherently utopian act is situated in the legacy of early twentieth century avant-garde and modernism supplemented by the postWWI impulse to change society through architectural design. An impulse wherein utopia is not understood only as fixed space, as was the case in the architectural aspects of 'classical utopias', but also as the mode of an activity (Margolin 1997; Heynen 1999; Henket, Heynen \& Allan 2002; Hvattum \& Hermansen 2004; Miles 2004; Coleman 2012; Lahiji 2019).

In the first part, I will discuss the nature of modernist architectural utopias and their manifested tendency to think that 'society can be changed through design'. I will briefly discuss how this definition has been criticized especially from the point of view of such prominent utopian theorists like Ernst Bloch and Theodor W. Adorno, who share the idea that political efficacy of architectural utopias, understood this way, is closer to ideological and even totalitarian political programs than societal liberation.

In the second part, I will outline a more politically nuanced critique towards the definition of modernist architectural utopianism from the point of view of its conformist engagement towards the prevailing society. Theoretically this can be traced especially to Manfredo Tafuri's reading that takes the afterlife of modernist utopianism as his point of reference. Tafuri's critical reading finds an empirical touchpoint in early twentieth century architectural utopianism, such as Russian Constructivism, The Bauhaus, New Frankfurt, the housing policies of socialist Red Vienna, and other modernist architectural movements, that are often considered socialist or left-leaning attempts to design society beyond classical nineteenth century capitalism. However, Tafuri saw their reformist attitude towards society failing to understand the simultaneous transformation of capitalism and for example how the ideas of socialist de-commodified housing were best realized throughout the reorganization of 
capitalism towards a Taylorist-Fordist mode of production. Here the utopian aspirations function as the reproduction of society - an aspect that is commonly referred to as ideological, especially in Marxist scholarship.

Tafuri's Marxist reading of modernist utopianism seems to reflect the general tendency to consider 'utopian' and 'Marxist' approaches as opposite poles. Here, however, especially Lefebvre's discussion of architectural utopias, examined in the third part, from another Marxist perspective offers another way to the problematic relationship between utopia and ideology. While Lefebvre's theory has significant similarities with Tafuri's as regards the ideological dimension of modernist utopianism, the focus of his critique is not in the relationship between utopia and ideology per se, but instead in different conceptualizations of architectural utopias. Lefebvre's attempt to come in terms with the problematic co-existence of the utopian and ideological dimension of modernist architecture is hence not based on the rejection of the notion of utopianism in general, but instead on the attempt to find another conceptualization of utopia moving from reformist conformism to experimentation with different possible modalities of the future.

In the final part, I think through the alternative approach offered by Lefebvre from the point of view of the hypothesis of this book: utopias as methods for social and political change. Rather than residing on the ideologically fixed blueprints, the conceptualization of architectural utopias from this point of view is more interested in experimenting with what is considered possible as a deliberate method for expanding political imagination towards new horizons.

\section{Modernist architecture as a degenerate utopia?}

The interplay between modernist architectural utopianism and its ideological connotations found in the works by Tafuri and Lefebvre deciphers a broader tension related to the role of architecture in the theories of art and politics. Here especially the contested legacy of modernist architectural utopianism serves as an empirical point of reference. Modernism in architecture refers here first and foremost to architecture's relationship to society rather than 
to any particular architectural style. It emerges from the avant-gardist attempt to think the boundaries between art and life anew. As Hilde Heynen suggests:

'The issues and themes around which the modern movement in architecture crystallized are related to the avant-garde logic of destruction and construction. Here too what was involved first of all was a rejection of the bourgeois culture of philistinism that used pretentious ornament and kitsch and which took the form of eclecticism. In its stead the desire for purity and authenticity was given precedence. All ornamentation was regarded as unacceptable; instead, authenticity was required in the use of materials, and it was thought that a constructional logic should be clearly visible in the formal idiom. In the twenties these themes also acquired a distinct political dimension: The New Building became associated with the desire for a more socially balanced and egalitarian form of society in which the ideals of equal rights and emancipation would be realized.' (Heynen 1999, 28.)

How is this then any different from any architectural utopias given that especially the classical conceptualization of utopias takes also often the shape of spatial geographical form? Picturing of ideal city implies always that architecture and city planning are ways to either produce or maintain ideal social forms and harmony (Pinder 2005). However, while this idea of the ideal city is largely present in modernist planning and architecture as well, there emerges another utopian impulse that goes beyond picturing a fixed spatial plan for an ideal society. Here utopias are considered more as an activity. By contesting and politicizing the questions associated to living and spatial structures of everyday life - modernist architecture directly mounts attacks towards previous modes of living and for example classical nineteenth century bourgeois conceptualization of interior and class and power -relations inherent in them. Hence, this destructive aspect of modernism puts forth a different utopian emphasis towards the classical construction of blueprints. Moreover, the problem with modernist utopianism is no longer the lack of politics per se (as in classical spatial utopias that imagine worlds in harmony beyond political conflicts), but the conceptualization of politics through reified forms of 
everyday life. This raises a question of whether modern architectural utopias are degenerate, as they do not offer radical negation from society, in the way in which for example utopian painting or literature are believed to offer.

Hence the issue is not only the relationship between architecture and utopia in general, but specifically the particular conceptualization of politics in the utopian aspirations of modernist architecture and the avant-garde. Additionally, this seems to constitute something of a challenge that still defines the future of utopian thought in thinking politically on architectural practices and their utopian aspirations (Henket, Heynen \& Allan 2002; Cunningham 2001). But are we talking about ideology or utopia here? Here a good point of reference is the discussion on the convolutions between art and politics within the Frankfurt school and critical theory more broadly. The central common denominator in these discussions is the idea that the utopian dimension of artwork resides in its capability to offer a counter-image, seeing utopia as a negation or counter-image of society rather than deliberately engaging with it. As architecture is necessarily physically rooted in the existing world, however, its utopian dimension appears highly problematic in these readings.

Addressing the relationship between artistic practice and emancipatory political theory and the tendency to consider critical and utopian dimension artwork to show a different world out-ofreach that is actually only as a wish for better being, Gabriel Rockhill, for instance, has shown that the very definition implies the exclusion of architecture. Rockhill maintains that 'regarding design and production, to begin with, architecture and public art almost always take place, in our day and age, in a constructed milieu, or at the very least within the charted territories of traversed landscapes. They cannot, therefore, be easily isolated from their immediate inscription in a larger sociopolitical space' (Rockhill 2014, 22). Considered from this point of view, modernist architectural utopias appear as 'degenerate utopias', combining too straightforwardly art and life and being hence examples of how art and politics should not merge (see Coleman 2013).

This pessimistic tone can be traced back especially to Theodor W. Adorno and Ernst Bloch, whose theories on art's utopian capability of showing alternative worlds remain influential. 
They both suggested, that the core of art's critical and utopian potential is to outline an autonomous expression of a different society, which is in many respects the opposite of, for example, the deliberate attempt to shape society by design having also ideological connotations. These readings have reinforced a certain pessimistic tone towards architecture in proceeding theories of art's role in critical theory defending art's autonomy and considering architecture as unable to propose any real utopian alternative when rather straightforwardly adopting and affirming the capitalist idea of rationalization as the core of modernity.

As already stated, these debates on the relationship between the utopian and the ideological dimension of architecture are primarily about modernist architecture. This is evident especially in Bloch's writings on the utopian function of art. As Nathaniel Coleman argues regarding the possibility to combine Blochian utopian thinking to architectural alternatives, 'Bloch identified the inextricable bond between Utopia and hope in almost everywhere but in architecture' (Coleman 2013, 135). Bloch maintains that modern architecture and its utopian aspiration 'cannot at all flourish in the late capitalist hollow space' given that it is 'far more than the other arts, a social creation' (Bloch 1988, 188). This resonated with Bloch's early work on the utopianism of artwork: for art to be utopian, it needs to have a certain transcendental aura that detaches itself from regular use and everyday objects. Bloch argues that modern architecture with its emphasis on function cannot detach artwork from the current state of things. Instead it is compatible with the modernist ideology of progress creating a 'hollow space of capitalism' (ibid.).

Similarly, with Bloch, Adorno argued that the revolutionary aspect of architecture cannot escape given social relations. Utopian and emancipatory aspirations in modern architecture were according to Adorno 'conditioned by a social antagonism over which the greatest architecture has no power: the same society which developed human productive energies to unimaginable proportions has chained them to conditions of production imposed upon them' (Adorno, cited in Leach 1997, 14). The utopian dimension of art, its ornamental addition that detaches itself from reality, cannot be found from architecture realized through material and social restrictions. These readings seem to already be anticipating that the true nature of the 
utopia of modernist architecture was somewhat of an ideological compromise which materialized through Fordism and Taylorism (Coleman 2012). This argument is most systematically argued by Manfredo Tafuri.

\section{Utopia turned ideology}

In 1969, Tafuri published a highly polemic article, Toward a Critique of Architectural Ideology, that was later expanded into the book Architecture and Utopia: Design and Capitalist Development (1973/1976). Challenging the prevailing art historical explanation of emergence of modern architecture, Tafuri, informed by Marxist thought, proceeded to see the development of new ideas of modernist architecture and design in a dialectical relationship with capitalist development. The 'utopia' proposed by modernist architects was for him in fact inseparable from the broader capitalist development of the time.

At stake in the criticism of utopianism was the question concerning the nature of the political efficacy of architecture. Rather than revolutionising the society, the conformist modern architecture, according to Tafuri, offered a reformist way to integrate new social demands into the reorganization of capital. In this way modernist architecture did not present a rupturing counter-image towards the contemporary society or any profound avant-gardist destruction, but instead ended up formulating a 'utopia serving the objectives of the reorganization of production' (Tafuri 1976, 98). This meant constant cross-overs between the Fordist and Taylorist mode of production and an avant-gardist experimental culture in the first part of the twentieth century: 'Design, as a method of organizing production more than of configuring objects, did away with the utopian vestiges inherent in the poetics of the avant-gardes. Ideology was no longer superimposed on activity-which was now concrete because it was connected to real cycles of production-but was inherent in the activity itself.' (ibid.)

This can be seen in the context of the broader question concerning reform or revolution in twentieth century Marxist thought. Here the reformist way implied the realisation of utopia in a strange reversed form in which architecture "becomes a pedagogical act and a means of 
collective integration' (ibid., 132). For Tafuri, the immersion and incorporation of utopian aspects of modernism into broader capitalist development can be understood through the Marxist concept of ideology. In this way Tafuri's reading is undoubtedly informed by (albeit not systematically discussed in relation to) Althusserian structural Marxism on the reproduction of capitalism through various 'ideological state apparatuses' in it (in this case most importantly, urban planning, housing, architecture, design etc.) that offers more complex reading of ideologies that just notions of 'false consciousness' (Althusser 2014). In this regard, Tafuri was informed also by Italian autonomist Marxism, including figures such as Antonio Negri, at the same time suggesting that the developments of Keynesian economics, strong welfare state and Fordist regime of capitalist accumulation based on somewhat mutual agreement and compromise between capital and (industrial) workforce (for Tafuri's political context, see Aureli 2008).

By emphasising the historical forms of ideological dimensions of architectural utopias, especially modernism, Tafuri's reading is also to be understood in terms of a 'classical' Marxist critique of utopias, in which the notion of ideology is associated primarily with non-materialist conceptualizations of history such as idealism and its utopian nature. By discussing this failure of non-materialist 'utopian' approaches especially in relation to architecture and urban planning, Tafuri is hence continuing a critique already familiar from Engels and his fundamental distrust toward other socialist movements and anarchist traditions, but above else the tradition of utopian socialism and its idealistic connotations. In the famous Zur Wohnungsfrage, Engels directly confronted this type of utopianism and argued that it provides little more than a bourgeois solution to the housing crisis and that housing is derivate to broader problems of capitalism that need to be overcome:

'The housing shortage from which the workers and part of the petty bourgeoisie suffer in our modern big cities is one of the innumerable smaller, secondary evils which result from the present-day capitalist mode of production. It is not at all a direct result of the exploitation of the worker as worker by the capitalist. This 
exploitation is the basic evil which the social revolution wants to abolish by abolishing the capitalist mode of production. ${ }^{24}$

This type of Marxist tradition builds itself on the critique of utopianism and its idealistic connotations, which is considered as an opponent to Marxism and historical materialism. The common theme from Engels to Tafuri among others, is a certain detachment between utopian social critique and the analysis of capital and materialist conceptualization of history. As stated by Tafuri: 'It is useless to propose purely architectural alternatives. The search for alternatives within the structures that condition the very character of architectural design is indeed an obvious contradiction of terms.' (Tafuri 1976, 181.) Seen this way, utopian traditions not only miss the point, but also to some extent reinforce the ideological dimension of capitalism through its reformist tendencies. In what follows, this contests the whole core of modernist architectural utopianism and the avant-garde: it is literally impossible to change society through design.

However, as I will argue in the next section, this type of conclusion covers primarily utopias as understood from the point of view of their outcomes and different pathways remain if one considers utopias primarily as action and process, immanently revolutionizing what is considered possible (see also Lakkala in this volume). Even though Tafuri's criticism offers a way to highlight the problems related to reformist tendencies of architectural utopias and their lack of critical analysis emerging, especially from the point of view of critique of ideologies and insights from historical materialism, I maintain the utopian aim of changing society through design is not necessarily to be interpret as an attempt to make blueprints, but it could be also characterized as a mode of activity: an experimental site for politics. This is based on another conceptualization found in the writings of Henri Lefebvre that is discussed in the following section.

\footnotetext{
${ }^{24}$ https://www.marxists.org/archive/marx/works/1872/housing-question/
} 


\section{From abstract utopianism to experimental utopias}

The work by Henri Lefebvre offers another conceptualization of the relationship between modernist architecture, utopias and the coexisting ideological dimension. ${ }^{25}$ Additionally Lefebvre, like Tafuri, emphasizes especially the ideological dimension of modernist utopianism. According to Coleman, for example, 'it is precisely the empty promises, false hopes and extravagant failures of modernist architecture and urbanism that preoccupied Lefebvre in much of his writings' (Coleman 2015, 19). However, at the same time Lefebvre never neglects the utopian aspiration of an especially modernist conceptualization of utopias as an activity altogether. Instead, there are two opposite conceptualizations of a utopia and proponents of utopias simultaneously coexisting:

'An opposition is continuously at work between abstract and concrete utopias. This enables us to distinguish utopists from utopians. (...) Abstract utopia relies on technocrats; they are the ones who want to build the perfect city. They concern themselves with the 'real': needs, services, transport, the various subsystems of urban reality, and the urban itself as a system. They want to arrange the pieces of a puzzle to create an ideal. Contrast this with concrete utopia, which is negative. It takes as a strategic hypothesis the negation of the everyday, of work, of the exchange economy. It also denies the State and the primacy of the political. It begins with enjoyment and seeks to conceive of a new space, which can only be based on an architectural project.' (Lefebvre 2014, 148.)

Here Lefebvre is largely following the distinction between an abstract and a concrete utopia, as outlined by Bloch (see Introduction), but strikingly in the context of urban planning and architecture, areas that Bloch considered generally anti-utopian (see also Coleman 2013; 2015). First, there are negative interpretations associated with (especially modernist) utopianism.

\footnotetext{
${ }^{25}$ Lefebvre also confronted Tafuri in person. They both were invited to a conference held in 1972 by the research group on urban sociology located at the Paris 10 University. In the conference, Lefebvre accused Tafuri of having a tendency of explaining everything as ultimately working for capitalism thus leaving no room for alternatives (Stanek 2011, 165-167).
} 
Abstract utopianism is frequently referred to as a scientific and positivistic utopia by Lefebvre, which can be understood as a conceptualisation of utopia that resides only in abstract representations of spaces which dismiss the experimental and transgressive aspects of utopian thinking (Lefebvre 1996, 151). For Lefebvre, this is the most obvious way to think of the spatial dimension of utopias (Lefebvre 2014, 141). Traditional or classical utopias (such as More, Campanella, Bacon) are in Lefebvre's theory 'characterized by an emphasis on architectural form, geometric designs and rigid spatial order'. From a more modern perspective, they also 'have a related concern with control, regulation and modes of surveillance' (Pinder 2005, 21).

In this sense, there are important parallels between Lefebvre and Tafuri regarding thinking architectural utopianism and ideology as intertwined. What Tafuri calls architecture as ideology, appears to Lefebvre as a somewhat abstract utopia understood as a conformist engagement and commitment to building a new society. This calls for an urban planning that would integrate new architectural solutions with societal reforms. However, while remaining critical towards general utopianism, and modernist architectural utopias in particular in a similar way to Tafuri, Lefebvre acknowledged that utopias can have a disintegrating role. This leads to an internal distinction between two types of utopias: 'While abstract utopia is a 'positive' extrapolation of the status quo, concrete utopia is 'negative,' that is to say it contradicts the premises of the current social order: the everyday defined by the division of labour, economy of exchange, and the state as the primary agent of economic regulation and political subjectivity.' (Lefebvre 2014, 151.)

For Tafuri, critical architecture practices as such cannot exist, but thinking architecture, urban planning and housing differently requires an entirely different society and a different economic system. Lefebvre offers a more complex argument regarding the role of relationships between architectural practices and the production of space under capitalism, and hence also a conceptualisation of utopia. Encapsulating the difference, Frank Cunningham has suggested that 'like Tafuri, he sees utopian visions as ideologically infused, but they can also serve in an experimental way to prompt challenges to existing structures, functions and forms' 
(Cunningham 2010, 270). Thinking utopian as 'a partisan of possibilities' rather than 'utopist', Lefebvre writes that:

'For me this term has no pejorative connotations. Since I do not ratify compulsion, norms, rules and regulations; since I put all the emphasis on adaptation; since I refute 'reality', and since for me what is possible is already partly real, I am indeed a utopian; you will observe that I do not say utopist; but a utopian, yes, a partisan of possibilities. But then are we not all utopians?' (Lefebvre 1984, 192.)

This leads to another conceptualization of utopias found in Lefebvre's work - to which he simultaneously refers to as both a concrete utopia and an experimental utopia. Lefebvre introduced the concept of an experimental utopia already in 1961 as a critique of what he called the post-war functional urbanism as the realised legacy of modernist utopianism, where the efficacy of architecture was primarily understood in terms of how it serves society and reproduces the conditions of production. Against this Lefebvre attempted to find different utopian connotations embodied in architecture as a category for mediating what is considered possible. For Lefebvre, this type of utopia is defined as 'explorations of human possibilities, with the help of the image and imagination, accompanied by an incessant critique and an incessant reference to the given problematic in the real' (Lefebvre 1961, see also Pinder 2015, 37).

Experimental utopia is thus contrasted with abstract utopianism and the reformist tendencies of modernist architecture. Whereas abstract utopianism, aimed at providing a certain blueprint for an ideal society beyond conflicts; the political logic of experimental utopias seems to be quite the opposite, creating disharmony and disintegration to the current state of things by expanding the scope of what is considered possible. To fully understand utopian practice as a dialectical movement between possible and impossible, blurring the boundaries between these two categories, Lefebvre maintains that it is necessary to understand utopias as a sphere for experimentation and invention of new ways of living, this also disintegrating the prevailing society and its space. Here utopia is not any grand ontological statement, but a tactical intervention to current state of things and a mediation between the possible and the 
impossible. To grasp this idea, Lefebvre used the concept 'transduction', familiar especially from natural sciences, to describe the conversion and transfer of different constituents:

'Transduction elaborates and constructs a theoretical object, a possible object from information related to reality and a problematic posed by this reality. Transduction assumes an incessant feedback between the conceptual framework used and empirical observations. Its theory (methodology), gives shape to certain spontaneous mental operations of the planner, the architect, the sociologist, the politician and the philosopher. It introduces rigour in invention and knowledge in utopia.' (Lefebvre 1996, 151.)

This approach comes close to what David Harvey, heavily inspired by Lefebvre's theory has called 'dialectical utopianism' situated in various architectural and spatial practices. It is based on existing concrete social relations and a material basis, but it simultaneously attempts to surpass them within (Harvey 2004). As such, it is an attempt that defines both the work by Lefebvre and Tafuri to show that Marxist thought and utopian thought can mutually coexist. Here a striking example is precisely both the success and the failure of modernist architecture and classical avant-garde for realizing that every political rupture requires a utopian envisioning of new space as the framework for becoming a political register:

'Change life! Change Society! These ideas lose completely their meaning without producing an appropriate space. A lesson to be learned from soviet constructivists from the 1920s and 30s, and of their failure, is that new social relations demand a new space, and vice-versa.' (Lefebvre 1991, 59.)

The simultaneous proclaimed failure stated by Lefebvre here is that the picturing of the impossible did not go far enough and was still articulated within the prevailing framework of the possible rather than beyond it. Regardless, the notion of this failure seems to be more of an affirmative critique. Compared to Tafuri, but also to Adorno and Bloch, Lefebvre's theory not only criticizes the history of architectural utopianism for their ideological function of reinforcing 
the status quo. It also acknowledges the possibility to function also as a form of social criticism by expanding political imagination through architectural forms, experimentations and projects.

Therefore, while remaining critical to the realization of architectural utopianism in the forms Tafuri would call ideology, Lefebvre never neglected the idea of an alternative space beyond capitalism. It remained a source for inspiration in later forms of experimental architecture. Even though Lefebvre does not exclude the connection between (modernist) architectural utopianism and its relation to capitalist development (as Tafuri does), he argues at least for methodological isolation as 'the only way forward towards clear thinking, the only way to avoid the incessant repetition of the idea that there is nothing to be done, nothing to be thought, because everything is 'blocked', because capitalism rules and co-opts everything, because the 'mode of production' exists as system and totality, to be rejected or accepted in accordance with the principle all or nothing' (Lefebvre 2014 , 4). This is largely echoed by Jameson, who in a similar manner is concerned that a Tafurian-style critique of certain problematic dimensions of particular architectural utopias nullifies the stimulus to think that the surroundings of our lives can be altered.

Here the experimentation related to utopia is understood as a transgressive activity. Going beyond Tafuri, the notion of utopianism of modernism is not rejected in general but their actual outcome is set against their original utopian aspirations. To conclude: compared to Tafuri's critique of utopianism, Lefebvre's understanding of architecture, understood from the point of view of experimental utopia, is not only a reflection of modes of production, but also a site of political struggle and an active ground for reclaiming different meanings, discourses, and interpretations. ${ }^{26}$

\section{Architectural utopias as methods for experimenting with the (im)possible}

\footnotetext{
${ }^{26}$ As Michael Gardiner suggests: "Lefebvre does not promote a dualistic transcendentalism in which daily life is denigrated, but rather an 'everyday utopianism' in which routine and creativity, the trivial and extraordinary, are viewed as productively intertwined rather than opposed.' (Gardiner 2004, 228.)
} 
Challenging Tafuri's reading on the ideological dimension of architectural utopias, Lefebvre considered architecture also as a medium for different practices, where collective subjectivities and their relations to political, social, and cultural form are opened up for contestation. Lefebvre's solution is not hence to reject utopianism in general, but instead to change the conceptualization of utopias from integration to experimentation. By rejecting the standard wisdom; that architectural utopia necessarily implies a blueprint, Lefebvre moves the emphasis towards experimental activity when thinking about utopias. This experimental dimension of utopias is understood as transgressive dynamics between the possible and the impossible, which redefines the notion of utopia.

In this sense, configuring the relationship between architecture and utopianism is not just a discussion on how architecture can contribute to thinking about utopian goals. Instead, it is about thinking political transformation itself: What type of act is architectural design? What does it bring to the world? How does it promote a different conceptualization of the future? How does it challenge the existing spatial orders of society? In this sense, architecture not only reflects utopian goals, but constructs them experimentally, bringing future possibilities to the active deliberation of the now.

What is the actuality of these positions for contemporary utopian studies? Based on this assessment, I suggest a re-introduction of Lefebvre's affirmative critique that considers architectural utopias as a sphere for experimenting what is considered possible as a pathway towards political change. Here utopia is not a fixed outcome, but more of a tool and a method. The methodological notion of utopias is associated especially with the work of Ruth Levitas, who proceeds to consider utopias not as ultimate goals but instead as processes where possible pathways for the future are examined as a methodological way to understand the possibilities for social transformation (Levitas 2013). ${ }^{27}$

\footnotetext{
${ }^{27}$ Here I am also informed by Nathaniel Coleman, who argues in a similar way, that the notion of utopia as method comes close to Lefebvre's conceptualization of utopia (Coleman 2014; 2015).
} 
While the discussion here is primarily historical, we outline that this emphasis offers more politically nuanced ways of considering utopias first and foremost as tools for political change in various areas of human activity. These challenge, especially the still dominant, Blochian way to detach utopias from concrete political struggles and the material existence of society and instead are situated in the counter-image of present day society and offer expressions for better being.

Understanding utopias only as expressions for better being is problematic, in the sense that this makes utopias take distance from society and politics, leaving little room for the actual potentiality of social and political change (Chrostowska \& Ingram 2017; see also Lakkala in this volume). After all, especially in the current political climate, it is not only a vague 'utopian wish' that is required, but more concrete, material and effective tools, utopias as methods for and committed to socio-political change even though there are always ideological connotations present in these types of attempts.

Thinking this in terms of how architecture can facilitate this type of social and political change, I have argued throughout this chapter that Lefebvre's theory offers one way to mediate these types of attempts to materialize utopian aspirations. Here again the notion of method is crucial. As Cathy Turner suggests, Lefebvre's somewhat partial isolation from a capitalist mode of production, or what Jameson calls an attempt to claim a semi-autonomous sphere for architecture at least partially separable from its ideological connotation, is first and foremost 'devised to allow or 'activate' an alternative or transgressive space in dialectical relationship to established possibilities' (Turner 2015, 4). Here the expected political outcomes are not in a future ideal society, but in the political negotiation of what can be thought.

The conceptualization of utopia in this way, is not limited only to Blochian wish-images or a Tafurian critique of ideologies, but it is also embodied in 'real' material forms where 'utopias embraces this tension between dreams and practice. It is grounded in the belief that what is pragmatically possible is not fixed independently of our imaginations, but is itself shaped by our visions' (Wright 2010, 6). The necessary task for thinking utopias as transformative political action is also to materialize them. This is a process of which architecture as configuring utopian 
spaces in actually existing forms is a good example. Utopias understood this way, as experimental mediums, aim not at providing a direct spatial setting for a revolution, but this type of utopianism is an immanent, revolutionary action in itself, constantly revolutionising what is considered possible and the boundaries of the given. The future is the open possible of becoming something else, utopias are methods for aesthetico-politically configuring that pathway.

\section{References}

Althusser, L. (2014) On the Reproduction of Capitalism: Ideology and Ideological State Apparatuses. London: Verso.

Aureli, P. V. (2008) The Project of Autonomy: Politics and Architecture Within and Against Capitalism. New York: Princeton Architectural Press.

Bloch, E. (1988) The Utopian Function of Art and Literature: Selected Essays. Cambridge, MA: MIT Press.

Coleman, N. (2012) 'Utopia and modern architecture?’ Architectural Research Quarterly 16 (4), 339-348.

Coleman, N. (2013) 'Building in empty spaces': Is architecture a 'Degenerate utopia'?' The Journal of Architecture 18 (2), 135-66.

Coleman, N. (2014) 'Architecture and Dissidence: Utopia as Method'. Architecture and Culture 2 (1), 44-58.

Coleman, N. (2015) Lefebvre for Architects. New York: Routledge.

Chrostowska, S. D. and Ingram, James D. (eds.). (2017) Political Uses of Utopia. New York: Columbia University Press.

Cunningham, F. (2010) 'Triangulating utopia: Benjamin, Lefebvre, Tafuri.' City 14 (3), 268-77. 
Cunningham, D. (2001) 'Architecture, Utopia and the Futures of the Avant-garde.' The Journal of Architecture 6 (2), 169-182

Gardiner, M. (2004) 'Everyday Utopianism: Lefebvre and His Critics.' Cultural Studies 18 (2-3), 228-54.

Henket, H.-J., Heynen, H. \& Allan, J. (eds.) (2002) Back from Utopia: The Challenge of the Modern Movement. Rotterdam: 010 Publishers.

Heynen, H. (1999) Architecture and Modernity. Cambridge, MA: MIT Press.

Hvattum, M. \& Hermansen, C. (eds.). (2004) Tracing Modernity. Manifestations of the Modern in Architecture and the City. London: Routledge.

Jameson, F. (2000) 'Architecture and the Critique of Ideology'. In K. M. Hayes (ed.) Architecture Theory since 1968. Cambridge, MA: MIT Press, pp. 440-462.

Lahiji, N. (ed.). (2012) The Political Unconscious of Architecture: Re-opening Jameson's Narrative. London: Routledge.

Lahiji, N. (2019) An Architecture Manifesto: Critical Reason and Theories of a Failed Practice. London: Routledge.

Leach, N. (ed.). (1997) Rethinking Architecture. London: Routledge.

Lefebvre, H. (1961) 'Utopie expérimentale: Pour un Nouvel Urbanisme'. Revue Française Sociologie 2 (3), 191-198.

Lefebvre, H. (1984) Everyday Life in the Modern World. London: Athlone Press.

Lefebvre, H. (1991) The Production of Space. Oxford: Blackwell.

Lefebvre, H. (1996) Writings on Cities. Oxford: Blackwell.

Lefebvre, H. (2014) Toward an Architecture of Enjoyment. Minneapolis: University of Minnesota Press. 
Levitas, R. (2013) Utopia as Method: The Imaginary Reconstitution of Society. Basingstoke: Palgrave Macmillan.

Mannheim, K. (1936) Ideology and Utopia. London: Routledge.

Margolin, V. (1997) The Struggle for Utopia. Chicago: University of Chicago Press.

Miles, M. (2004) Urban Avant-gardes: Art, Architecture and Change. New York: Routledge.

Moylan, T. \& Baccolini, R. (eds.). (2007) Utopia Method Vision: The Use Value of Social

Dreaming. Oxford: Peter Lang.

Pinder, D. (2005) Visions of the City: Utopianism, Power and Politics in Twentieth-century Urbanism. New York: Routledge.

Pinder, D. (2015) 'Reconstituting the Possible: Lefebvre, Utopia and the Urban Question'. International Journal of Urban and Regional Research 39 (1), 28-45.

Rockhill, G. (2014) 'The Forgotten Political Art par excellence? Architecture, Design and the Social Sculpting of the Body Politic' In N. Lahiji (ed.) The Missed Encounter of Radical Philosophy with Architecture. London: Bloomsbury, pp. 19-33.

Stanek, L. (2011) Henri Lefebvre on Space: Architecture, Urban research, and the Production of Theory. Minneapolis: University of Minnesota Press.

Tafuri, M. (1976) Architecture and Utopia: Design and Capitalist Development. Cambridge, MA: MIT Press.

Turner, C. (2015) Dramaturgy and Architecture: Theatre, Utopia and the Built Environment. New Dramaturgies. Basingstoke: Palgrave Macmillan.

Wright, E. O. (2010) Envisioning Real Utopias. New York: Verso. 